\title{
Sobre la novel·la grega en Curial e Güelfa: la novella de Cimone
}

\author{
[On Greek novel in Curial e Güelfa: the novella of Cimone]
}

\author{
Sònia Gros Lladós \\ UNED \\ sgroslla@gmail.com
}

\begin{abstract}
Resum: L'objectiu d'aquest treball és aprofundir en l'estudi de les fonts grecollatines del Curial e Güelfa i, en particular, en les connexions entre la novel-la cavalleresca catalana i les antigues novel-les gregues d'amor $\mathrm{i}$ aventures, un gènere que ha passat força desapercebut als investigadors. Suggerim l'anàlisi dels motius novel-lescos mitjançant la provada relació intertextual de l'obra catalana amb la novella decameroniana de Cimone (V.1). Defensem el coneixement del gènere per part de Boccaccio a partir de l'anàlisi dels textos i subratllem la circulació del manuscrit Laurentianus Conventi Soppressi 627 pels ambients nord-italians del Quatre-cents. La figura de l'humanista i pedagog Guarino de Verona emergeix com a possible nexe de contacte amb l'ambient de creació de la novel-la cavalleresca catalana.
\end{abstract}

Paraules clau: Curial e Güelfa, Boccaccio, Decameron, novel·la grega, Guarino de Verona

Aвstract: This paper aims to deepen in the study of Greco-Roman sources of Curial e Güelfa. In particular, we will analyse the connections between the Catalan chivalric novel and ancient Greek romances, a genre that has been rather overlooked by scholars. We suggest the analysis of novel motifs through the proven intertextual relationship with the novella of Cimone (Decameron, V.1). We defend Boccaccio's knowledge of Greek romances and we emphasise the circulation of Ms. Laurentianus Conventi Soppressi 627 in the humanist circles of Northern Italy in the XVth century. The famous humanist and pedagogue Guarino Veronese appears as a possible nexus with the cultural environment of Catalan novel's creation.

KeYWORDs: Curial e Güelfa, Boccaccio, Decameron, Greek novel, Guarino Veronese

Recepció: 07/07/2018. Acceptació: I I/07/2018. Publicació: I6/I I/2018

REVISTA VALENCIANA DE FILOLOGIA / I I (2OI8) p. 85-IO8 / ISSN 0556-705X DOI IO.28939/RVF.V2I2.40 


\section{Les fonts grecollatines en Curial e Güelfa}

La recerca sobre la presència dels autors grecollatins en la novel-la cavalleresca ha avançat enormement en els darrers anys. Una excel·lent i actualitzada síntesi la podem trobar en la recent publicació de la tesi doctoral d'Abel Soler (2018), on l'investigador recull exhaustivament la recerca duta a terme per nombrosos especialistes sobre aquest àmbit d'estudi. Pel que fa als autors grecollatins, Soler subratlla la presència de La República de Plató, extremadament reveladora de la inserció de l'obra en un context nord-italià, i, específicament, en els cercles neoplatònics de mitjan segle xv. Soler mostra indicis de connexions amb l'entorn d'Enyego d'Àvalos, camarlenc d'Alfons el Magnànim, el qual proposa com a autor de la novel-la, i concilia les idees platòniques amb determinats plantejaments aristotèlics vigents entre els humanistes italians com la defensa de la vida activa o el control racional de les passions. Soler repassa exhaustivament les traces dels més il-lustres autors llatins recopilant les recerques dels darrers decennis, a les quals afegeix nombroses troballes pròpies, de Ciceró a Sèneca, Macrobi, Boeci, Quintilià, Plini el Vell, Juli Cèsar, Sal-lusti, Valeri Màxim, Titus Livi, Vegeci, Frontí o Apuleu. Entre els poetes, aprofundeix en la petja fonamental de l'Eneida de Virgili, ben estudiada pels especialistes des de fa dècades, o les Metamorfosis d'Ovidi, sense oblidar l'empremta d'elegíacs com Properci o Catul, i altres grans noms com Persi, Lucà, Juvenal o Estaci. Caldria afegir-hi, en el cas d'Horaci, noves dades (Gros 2018). En qualsevol cas, autors clàssics, tots ells, que Soler documenta en la biblioteca del camarlenc Enyego d'Àvalos. Entre els autors grecs, Soler explora empremtes de Xenofont, Plutarc, Isop, o Homer amb més profunditat, escriptors accessibles a l'autor anònim mitjançant el coneixement de traduccions llatines, la qual cosa el condueix una altra vegada a l'àmbit de la Itàlia de la primera meitat del segle $\mathrm{XV}$, on aquestes traduccions, inexistents encara a la península Ibèrica amb la notòria excepció de Plutarc i Tucídides, començaven a proliferar. Més agosarades i dignes d'una anàlisi reposada són les propostes referents a Teognis, Llucià, Filòstrat o Píndar, que Soler relaciona amb la divisa del cavaller Ans anvie que pitié. A aquests autors caldria sumar la recentíssima aportació sobre l'ombra

REVISTA VALENCIANA DE FILOLOGIA / I I (20I8) p. 85-IO8 SÒNIA GROS LLADÓS

Sobre la novel-la grega en Curial e Güelfa: la novella de Cimone / 86 
d'Èsquil en l'episodi del Parnàs (Redondo 2018). Inexplicablement en un treball tan prolix, Soler oblida les connexions amb la novel-la grega (i bizantina), el gènere antic més proper a l'obra catalana $\mathrm{i}$ que $\mathrm{ja}$ ha rebut en els darrers temps l'atenció d'alguns investigadors. D'una banda, s'han analitzat nombrosos motius característics de la novel·la grega presents en el Curial e Güelfa a partir de les intertextualitats documentades amb la novella II.7 del Decameró (Gros 2014). De l'altra, Pomer ha examinat la funció de les cartes d'amor en la novel-la catalana, suggerint una influència directa dels novel-listes grecs (2014).

\section{La pervivència de la novel·la grega en les literatures modernes}

És ben conegut que la influència de la novel.la grega ${ }^{1}$ en les literatures modernes es produeix principalment a partir del Renaixement, amb la preeminència de Dafnis $i$ Cloe de Longus, obra que podem rastrejar ja en l'Arcàdia de Sannazaro (ca.1481), i que té una presència cabdal en altres textos com l'Arcàdia de Sydney o l'Astrea d'Honoré d'Urfé (1607). L'influx de la novel-la grega no es redueix a l'obra de Longus sinó que s'estén a altres com ara les novel-les d'Heliodor i Aquil-les Taci, com s'observa en La tempesta (1611) de William Shakespeare (Rojas 2012). ${ }^{2}$

Les novel-les gregues es difongueren a bastament per tot Europa, en especial a França, Anglaterra i Itàlia, fins al punt que s'ha arribat a considerar que "Greek romance is a major fabric of Renaissance narrative and drama» (Gesner 1970: VIII). A la península Ibèrica, la novel-la s'introdueix en data tardana però la influència serà notable en les lletres castellanes dels segles XVI

1 Atès l'enfocament d'aquest treball, obviem la discussió sobre la conceptualització del gènere que coneixem habitualment com a novel-la grega, el catàleg canònic d'obres incloses i altres aspectes més generals com la pròpia denominació o les característiques del públic receptor de les obres. Per a una síntesi recent d'aquesta qüestió vegeu Ruiz (2006), Whitmarsh (2008: 2-14) i Torres (2009).

2 Sobre aquesta qüestió vegeu el treball de Rojas (2012: 15-27), en què s'analitzen alguns motius de la comèdia de Shakespeare característics de la novel·la grega, com és el cas de la tempesta, la separació dels amants o el manteniment de la castedat.

REVISTA VALENCIANA DE FILOLOGIA / I I (2OI8) p. 85-IO8

SÒNIA GROS LLADÓS

Sobre la novel-la grega en Curial e Güelfa: la novella de Cimone / 87 
i XVII, incloses terres americanes, com testimonia l'estimació de Cervantes per Heliodor en la introducció del seu Persiles (1617). Lope ja havia publicat el Peregrino en su patria el 1604 (Carilla 1968: 155-167). Se n'ha assenyalat també la presència en la novel-la cavalleresca de Damasio de Frías y Balboa Lidamarte de Armenia (1568) (García Gual 2007: 100). La traducció més antiga que es conserva de les Etiòpiques a l'espanyol, obra de Francisco de Vergara, es publicà el 1548, a partir de la cèlebre versió francesa d'Amyot (1547), la primera a una llengua moderna (García Gual 2007: 98). La segona, anònima, s'edità a Anvers el 1554. Fou, tanmateix, més influent la de Fernando de Mena (1587), molt probablement la que utilitzà Cervantes. En el cas d'Aquil-les Taci la difusió de l'obra fou encara més tardana. La primera traducció, coneguda amb el títol de Los más fieles amantes Leucipe y Clitofonte, obra de Diego de Agreda y Vargas, va ser realitzada sobre la traducció a l'italià i es publicà l'any 1617 (Carilla 1966: 280). Caldrà, en canvi, esperar fins a 1880 per veure la traducció al castellà de Dafnis y Cloe de Juan Valera, novel·la ben coneguda, però, en altres llengües modernes. Quant a Cal-lírroe i les Efesíaques, no s'han traduït al castellà fins al segle Xx. Recentment, però, s'ha documentat una traducció al castellà fins ara desconeguda de les Efesíaques a l'Academia Real de Historia de Madrid, datada a la primera meitat del segle xIx (Hualde 2015). No hi ha constància de traduccions d'aquestes obres al català fins fa pocs anys, amb la de Longus per part de Jaume Berenguer (1963) i les Efesíaques, a càrrec de Carles Miralles (1967).

Malgrat aquest esclat renaixentista, cal admetre, però, la presència de la novel-la grega en dates força més primerenques. En primer lloc, com és ben conegut, la novel-la grega antiga (s. I-IV) origina la narrativa bizantina d'amor $i$ aventures, en vers i en prosa, l'anomenada en propietat novel-la bizantina (s. XII-Xv). Del Rodant i Dosicle de Teodor Pròdrom i Drosil-la $i$ Càricles de Nicetes Eugenià a les darreres obres anònimes com l'Aquil.leida, ja en el segle xv. Deixant de banda el Libro de Apolonio castellà (ca. 1250), veritable novel.la en vers derivada directament de la Historia Apollonii regis Tyri, la proximitat d'aquest gènere a l'amour courtois és ben coneguda (Miralles 1967: 33, 65). El roman Floire et Blancheflor, conservat en dues versions franceses del

REVISTA VALENCIANA DE FILOLOGIA / I I (20I8) p. 85-IO8 SÒNIA GROS LLADÓS

Sobre la novel-la grega en Curial e Güelfa: la novella de Cimone / 88 
segle XII, presenta l'esquema argumental característic de les novel-les gregues que han sobreviscut. També ho fan la versió italiana del segle XIII, Il cantare de Fiorio e Biancafiore, i la versió bizantina del xiv, Flòrios i Platsiaflora, que ofereix episodis nous respecte a les versions occidentals.

S'ha suggerit, d'altra banda, que la influència grega $\mathrm{i}$ bizantina en les novel-les de cavalleries occidentals provindria no de contactes amb la pròpia literatura bizantina sinó més aviat de novel-les antigues que haurien subsistit lluny de Bizanci o de terres gregues, com la de Caritó a Síria o la Vida d'Isop al sud d'Itàlia (Perry 1967: 347), o en tot cas mitjançant la intermediació de textos àrabs o textos grecs redactats a l'Àsia occidental en àrees de domini musulmà. Pel que fa a la península Ibèrica, l'empremta arribaria als textos de l'anomenada novela sentimental com ara el Siervo libre de amor (ca. 1430) o la Cárcel de amor (1450).

\section{Boccaccio i la novel-la grega}

Els contactes de Boccaccio amb la literatura grega s'inicien en la seva joventut, durant l'estada a Nàpols, actiu nucli cultural amb estrets contactes amb el món àrab i bizantí. De la mà de personalitats com Cino da Pistoia, Andalò di Negro o Paolo da Perugia, el jove Boccaccio accedeix entusiasmat a lectures del món antic, entre les quals textos desconeguts de la literatura grega i bizantina, que descobrirà a la magnífica biblioteca reial gràcies a Paolo da Perugia (Gros 2014: 114-116; Hernández 1997). L'interès per la cultura grega s'accentua anys més tard, cap al 1360, amb l'encontre personal amb Leonzio Pilato, amb qui s'iniciarà en l'estudi i la lectura de textos de la llengua grega, i el foment de l'ensenyament i les traduccions d'autors grecs com Homer o Eurípides. La tasca de Boccaccio esdevindrà crucial en el projecte cultural humanístic, posant en relleu la necessària unitat de la cultura grecollatina per a una comprensió ajustada de l'antiguitat clàssica (Branca 1991: L; Hernández 2005: 38).

Pel que fa a l'influx de la novel.la grega en l'obra de Boccaccio, ha estat valorat de manera divergent per la crítica. En el cas del Filocolo (1337-1339),

REVISTA VALENCIANA DE FILOLOGIA / I I (2OI 8) p. 85-IO8

SÒNIA GROS LLADÓS

Sobre la novel.la grega en Curial e Güelfa: la novella de Cimone / 89 
una obra de joventut, hi ha un consens més ampli que el text palesa molts dels trets característics d'aquest gènere $\mathrm{i}$ «lifts and ennobles the Greek romance tradition if only in the treatment of the theme of natural or instinctive love and the persistence of such love against all obstacles» (Gesner 1970: 26). L'obra de Boccaccio sembla derivar de Floire et Blancheflor, probablement en una versió francesa, a la qual alguns estudiosos atribueixen un origen grec anterior. Ofereix en un motlle cavalleresc nombrosos motius característics de la novel-la antiga com la bellesa divina dels herois, les tempestes, els somnis, la conjunció del plaer sensual amb un amor virtuós i cast, el paper rellevant de la Fortuna, adversa als amants, la intervenció de les divinitats: Venus, Eros, Apol·lo, Àrtemis, Hèlios. Fins i tot, un marcat retoricisme en l'estil.

Quant al Decameró, creiem que Boccaccio hi inclou igualment molts materials procedents de la novel-la antiga, que sovint modifica, imbrica o adapta a la funció d'entreteniment i d'apologia d'un erotisme natural de l'obra, reutilitzant magistralment els recursos narratius, o adoptant nous enfocaments còmics, fins i tot paròdics, dels recursos que el gènere li oferia. $S$ 'ha assenyalat la influència en les novelle II.6, II.7, IV.4, V.1, V.2 i X.8 (Gesner 1970). Totes aquestes amb intertextualitats ben documentades en el Curial e Güelfa (Gros 2015). La novella de madonna Beritola (II.6) «seems to be almost pure Greek romance in its separation plot as well as in some of its incidents» (Gesner 1970: 27). El relat de la musulmana Alatiel (II.7) constitueix un autèntic compendi de motius de la novel·la grega en clau paròdica (Gros 2014). La novella IV.4 relata l'enamorament, separació, viatge per mar i atac de pirates, segrest i final tràgic de Gerbino i la filla del rei de Tunis, una molt probable reelaboració de l'episodi del rapte i falsa decapitació de l'heroïna en Leucipe i Clitofont. Perry, basant-se en les observacions de Rohde, indicava la possible influència de la novel-la avui perduda, Cypriaca, en el relat primer de la cinquena Jornada, la història de Cimone i Efigenia (1967: 348). Es tracta d'un relat d'ambientació grega, desenvolupat en l'illa de Xipre, en un entorn de topònims i antropònims lògicament hel-lènics. L'acció —amor i aventures— es desenvolupa entre pirates, peripècies per mar i la constant presència de la Fortuna, adversa als amants. El motiu central de la transformació per amor de l'enamorat en un home nou i

REVISTA VALENCIANA DE FILOLOGIA / I I (20I8) p. 85-IO8 SÒNIA GROS LLADÓS

Sobre la novel-la grega en Curial e Güelfa: la novella de Cimone / 90 
del poder civilitzador de l'amor entronca directament amb la trama de Cal-lístenes i Cal·lígone de la novel·la d'Aquil·les Taci (Gesner 1970: 30). La novella V.2 narra la separació, peripècies adverses, reconeixement i final feliç d'una parella d'enamorats, Gostanza i Martuccio. S'ha postulat que la novella X.8, una de les més cèlebres del Decameró i amb més projecció posterior en les llengües modernes, procediria de la reelaboració d'una novel-la grega perduda, a partir de la versió francesa d'Athis et Prophilias. Amor a primera vista, intercanvi d'identitats, separació (en aquest cas, de la parella d'amics, Gisippo i Tito), viatges i desventures d'un d'ells, acusacions d'assassinat, presó, condemna a mort i final feliç amb la salvació a temps de l'amic.

La connexió d'aquestes narracions decameronianes amb el text del Curial ha estat identificada i se n'ha subratllat la rellevància en el rerefons de la novel·la (Gros 2015). La novella II.7 ja va ser objecte d'un estudi detallat des de la perspectiva dels motius de la novel-la antiga a partir de les intextualitats detectades amb el Decameró (Gros 2014). No farem referència en aquest treball a la presència d'Apuleu, l'obra del qual ofereix uns trets marcadament diferenciats, incloent-hi l'element humorístic i realista, i la paròdia de les convencions del gènere sentimental. Ja ha estat tractat, quant a les relacions amb el Curial, parcialment en altres treballs (Gros 2014, 2015, 2016) i creiem que mereix una anàlisi exclusiva. Tampoc abordarem, per motius diferents, les altres novel-les llatines: ni el Satiricó, pel caràcter fragmentari de l'obra i les peculiaritats de la seva difusió, ni la Historia Apolloni regis Tyri, la més coneguda de les novel-les antigues en el període medieval, sobre la qual es poden trobar algunes notes disperses en Gros (2015), i que, ben al contrari, demana un estudi en profunditat. Incidirem ara en l'anàlisi d'aquestes relacions amb la novel-la antiga a través d'un altre relat boccaccià: la novella de Cimone.

\section{La novella de Cimone i Curial e Güelfa}

Miralles estableix els elements característics de l'esquema argumental del gènere de l'antiga novel.la grega — la bellesa dels herois, l'amor i l'aventura-i

REVISTA VALENCIANA DE FILOLOGIA / I I (20I8) p. 85-IO8

SÒNIA GROS LLADÓS

Sobre la novel·la grega en Curial e Güelfa: la novella de Cimone / 9I 
subratlla un conjunt variat de motius novel-lescos que es repeteixen en aquestes obres (1968: 51-64). Bellesa extraordinària, quasi divina dels protagonistes, que ocasiona contínues desgràcies i desventures; amor idealitzat, ingenu, sensual però virtuós, com a motor gairebé únic de l'existència dels herois; poder de la Fortuna, que origina la separació dels amants, sovint amb viatges perillosíssims, atacs de lladres i de pirates, tempestes i naufragis. Analitzarem tot seguit aquests motius en la novella V.1 del Decameró, prenent en consideració la relació intertextual amb la novel-la cavalleresca catalana.

La novella de Cimone (V.1) va ser posada en relació amb el Curial e Güelfa per primera vegada per Gros (2011: 607-618) i sintetitzada posteriorment per Gros (2015: 256-264). En ambdues publicacions, a les quals remetem, es recullen i s'analitzen les intertextualitats documentades entre els dos textos. Recentment, Abel Soler ha explorat alguns punts amb més profunditat, postulant una relació del personatge de Cimone amb el possible dedicatari de la novel·la, Ferran, duc de Calàbria (2018: II: 733-734). El nostre objectiu és aprofundir en l'anàlisi des d'una nova perspectiva: la del text boccaccià com a intermediari entre la tradició novel-lesca de l'Antiguitat i la novel-la cavalleresca catalana. Vittore Branca indicava en relació amb aquest relat, similar al II.7 o al IV.4, que «la novella sembri rivelare una filigrana di romanzo alessandrino» (1991: 593, n.1) i, tot i que no identificava cap font concreta, esmentava diversos autors clàssics. Al seu parer, el més interessant com a trama en clau novel-lesca és «l'insistenza onde il tema della bellezza e dell'amore, quali miracolose forze educatrici, ritorna nell'opera del B.» (1991: 593, n.1), motiu present en moltes altres obres de l'escriptor. I, en efecte, la narració, que s'insereix en una Jornada dedicada als amors amb finals feliços, se'ns presenta des de la rúbrica inicial amb l'esquema argumental característic d'aquest gènere:

Cimone amando divien savio e Efigenia sua donna rapisce in mare: è messo in Rodi in prigione, onde Lisimaco il trae, e da capo con lui rapisce Efigenia e Cassandrea nelle lor nozze, fuggendosi con esse in Creti; e quindi, divenute lor mogli, con esse a casa loro son richiamati. (1991: 593)

REVISTA VALENCIANA DE FILOLOGIA / I I (20I8) p. 85-IO8 SÒNIA GROS LLADÓS

Sobre la novel-la grega en Curial e Güelfa: la novella de Cimone / 92 
Enamorament i separació dels protagonistes, raptes, viatges atzarosos per mar, presó i peripècies pel Mediterrani oriental, matrimoni i final feliç per als enamorats, constituïen els elements narratius habituals en la trama de la novel.la grega d'amor i aventures. Subordinats al tema central d'aquestes obres: l'amor totpoderós, idealitzat, com a únic motor i sentit de l'existència dels amants.

Revisem tot seguit els principals motius de la novel-la grega que detectem en la narració de Cimone.

1. L'ambientació temporal, en un temps passat indeterminat. El relat, segons explica el narrador de la novella, procedeix de la lectura de textos antics, emprant el mateix recurs que utilitzarà l'anònim del Curial: «sì come noi nell'antiche istorie de' cipriani abbiam già letto» (1991: 594). La posterior menció, però, als càrrecs d'algun dels personatges no s'adiu amb el període antic. És el cas de Lisimaco, «appo il quale quello anno era il sommo maestrato de' rodiani» (1991: 602). Dins del relat, l'enamorament es produeix en la primavera, durant el mes de maig. El temps propici per a l'amor, com mostra paradigmàticament Dafnis $i$ Cloe, la novel-la grega amb una composició temporal més acurada. El ritme morós d'algunes escenes alterna equilibradament amb la precipitació en la narració d'altres episodis.

2. L'ambientació espacial -Xipre, Rodes i Creta, en aquest cas-, concorda amb força exactitud amb la d'aquests tipus de textos. Els tres indrets són habituals en les novel-les antigues. A les Efesíaques, els protagonistes es retroben finalment al temple d'Hèlios a Rodes, després que l'heroi volti, en el tram final del relat, per nombrosos llocs. Concretament, partint de Sicília Habròcomes visita precisament Creta, Xipre i finalment l'illa de Rodes. A la novel-la de Caritó, cap al final de la narració, els grecs fugen a Xipre, on reten culte a Afrodita. La connexió amb la novel-la perduda Cypriaca, resulta de difícil justificació, més enllà de la coincidència en la ubicació, atès que sembla que aquest text, atribuït a Xenofont de Xipre i actualment perdut, versava sobre els amors incestuosos de Cínires i la seva filla Mirra (García Gual 1991: 296). Les Etiòpiques i la novel-la d'Aquil-les Taci s'ambienten igualment en indrets de la Mediterrània oriental com Egipte o fins a Etiòpia en el cas de la primera. L'itinerari que traça Boccaccio per als protagonistes en el seu relat resulta coherent, a diferència del

REVISTA VALENCIANA DE FILOLOGIA / I I (20I8) p. 85-IO8 SÒNIA GROS LLADÓS

Sobre la novel-la grega en Curial e Güelfa: la novella de Cimone / 93 
que succeeix en algun dels textos grecs, on els personatges efectuen autèntiques ziga-zagues sense sentit per la Mediterrània (Hägg 1983: 156-7).

Pel que fa a l'escena de l'enamorament, es produeix en un tòpic locus amoenus, en un entorn natural que propicia la delicada sensualitat de l'episodi, amb una evocació de referents clàssics diversos (Gros 2015: 258). A més, el marc es destaca doblement, ja que la novella s'insereix en el relat de l'entreteniment de la brigata, que prèviament s'ha distret en un entorn molt similar. A trenc d'alba, com el cèlebre i imitat començament de les Etiòpiques, s'inicia la introduzione: «Era già l'oriente tutto bianco e li surgenti raggi per tutto il nostro emisperio avevan fatto chiaro» (1991: 593). Aleshores Boccaccio ofereix els «dolci canti degli uccelli» (1991: 593), que refilen alegres als arbres i agradables passejos campestres per «le rugiadose erbe» (1991: 593), abans de tornar per refer-se de la calor de migdia "con ottimi vini e con confetti» (1991: 593) i distreure's «per lo dilettevole giardino» (1991: 593). Alegres danses, amb instruments i cançons, precedeixen la reunió de la colla que escolta la narració. L'atmosfera amable i acollidora es repeteix en l'escena de l'enamorament, en què s'accentua el to de suau erotisme:

[...] passato già il mezzodì, passando egli da una possessione a un'altra con un suo bastone in collo, entrò in un boschetto il quale era in quella contrada bellissimo, e, per ciò che del mese di maggio era, tutto era fronzuto. Per lo quale andando, s'avenne, sì come la sua fortuna il vi guidò, in un pratello d'altissimi alberi circuito, nell'un de' canti del quale era una bellissima fontana e fredda, allato alla quale vide sopra il verde prato dormire una bellissima giovane con un vestimento indosso tanto sottile, che quasi niente delle candide carni nascondea, e era solamente dalla cintura in giù coperta d'una coltre bianchissima e sottile. (1991: 596)

Boccaccio recrea un bucolisme artificial i idíl-lic, tot evocant el valor simbòlic de la primavera esplendorosa de Dafnis $i$ Cloe i recreant la sensualitat pagana de l'obra. El fins ara desgraciat Cimone inicia, vençut pel poder de l'amor, un camí similar al dels pastors de Longus.

REVISTA VALENCIANA DE FILOLOGIA / I I (20I8) p. 85-IO8 SÒNIA GROS LLADÓS

Sobre la novel-la grega en Curial e Güelfa: la novella de Cimone / 94 
3. Conseqüentment amb l'ambientació, també són grecs els antropònims dels personatges i, en algun cas, habituals en la novel·la grega. Així succeeix amb Aristippo, el pare del protagonista, nom d'un personatge de les Etiòpiques. Altres evoquen, com és el cas de Cimone, el de Cimó d'Atenes, fill de Milcíades, el conegut polític i estrateg atenès, malgrat que el narrador aclareix el significat del terme com a sinònim de bèstia. Soler indica l'atleta grec Quimó com a antecedent antic evocat per Boccaccio (2018: III, 1877, n. 4532). Les ressonàncies tràgiques d'Efigenia són evidents així com també les de Cassandrea, variant que trobem en el còdex Hamilton i que apareixia com a Cassandra en versions anteriors (Gros 2015: 257). El mateix podem dir de Pasimunda, Ormisda o Lisimaco.

4. La Fortuna «non stabile» $\mathrm{i}$ «invidiosa» hi té un paper crucial, ja que ocasiona les diverses desventures dels amants, que sovint entonen planys contra la seva acció. És la transposició de la Tóxๆ grega amb una funció similar a la de les novel-les antigues. La Fortuna ha fet que Aristippo tingui un fill com Cimone. La Fortuna, que ha concedit a Cimone la possessió d'Efigenia, «subitamente in tristo e amaro pianto mutò la inestimabile letizia dello innamorato giovane» (1991: 599). La mateixa Fortuna afavorirà el feliç desenllaç: «quasi pentuta della subita iniuria fatta a Cimone, nuovo accidente produsse per la sua salute» (1991: 601).

5. El relat es desenvolupa en un context exclusivament pagà. Els déus, sense més concreció, són els responsables de la marxa dels esdeveniments, castigant els amants, tal com es plany Efigenia davant la tempesta que amenaça el vaixell: «affermando per niuna altra cosa quella tempestosa fortuna esser nata, se non perché gl'iddii non volevano che colui, il quale lei contra li lor piaceri voleva aver per isposa, potesse del suo presuntuoso disiderio godere» (1991: 602).

6. Els joves protagonistes són d'origen noble i ric, i sobretot estan dotats d'una bellesa extraordinària, comparable a la dels déus. Són els passatges que veiem que reaprofita principalment l'autor del Curial. Nobles i rics són els protagonistes, Cimone i Efigenia, i les seves famílies. Aristippo és «nobilissimo uomo» i «ricchissimo» (1991: 594). Cimone «di grandezza e di bellezza di corpo tutti gli altri giovani trapassava» (1991: 594). La jove és «bellissima»,

REVISTA VALENCIANA DE FILOLOGIA / I I (20I8) p. 85-IO8

SÒNIA GROS LLADÓS

Sobre la novel-la grega en Curial e Güelfa: la novella de Cimone / 95 
«la più bella cosa che già mai per alcun vivente veduta fosse» (1991: 596), fins al punt que Cimone, en contemplar-la, «dubitava non fosse alcuna dea» (1991: 596). Aquest és un dels trets, com vèiem, més característics de les novel-les gregues. La bellesa extraordinària, sobrehumana, caracteritza sempre els herois d'aquests relats, comparats freqüentment amb divinitats i personatges del mite clàssic. Especialment en la novel-la de Caritó, la bellesa esdevé un motiu central. Cal-lírroe és comparada repetidament, fins i tot adorada per la multitud, amb Afrodita, també amb Ariadna i Leda, i l'aparició de la jove al palau de Mitrídates evoca l'admiració homèrica de la bellesa d'Helena a les muralles de Troia; Quéreas és parangonat amb Aquil.les i Hipòlit. És igualment proverbial la bellesa d'Àntia i Habròcomes, com la dels protagonistes de les altres novelles conservades. Els trets subratllats en la descripció física de les heroïnes són tòpics, com els d'Efigenia: sobre una pell blanquíssima sobresurten «i capelli, li quali d'oro estimava, la fronte, il naso e la bocca, la gola e le braccia e sommamente il petto» (1991: 597). Boccaccio deixa per al final el tret més rellevant de la bellesa de la noia, el que provoca l'enamorament fulminant i definitiu: els ulls.

Segons les convencions del gènere, la bellesa és un reflex de la noblesa dels personatges, que mostren un capteniment audaç i valent, també en l'àmbit amorós, sempre induït per motivacions elevades. En el cas d'aquesta novella de Boccaccio, però, la iniciativa correspon gairebé en exclusiva als personatges masculins (Cimone i Lisimaco), els quals actuen amb coratge i determinació. «Fiero come un leone» (1991: 600) assalta Cimone la nau d'Efigenia quan és necessari, però amb magnanimitat i bons sentiments, perdonant la vida i conservant els béns als rodis.

7. L'enamorament es produeix, com comentàvem, a través de la mirada, de manera sobtada i poderosa, com les fletxes d'Eros. Quan finalment Cimone contempla els ulls de la bella Efigenia, «come gli occhi di lei vide aperti, così in quegli fiso cominciò a guardare, seco stesso parendogli che da quegli una soavità si movesse la quale il riempiesse di piacere mai da lui non provato» (1991: 596). És un amor sensual però en tot moment cast i contingut. S'insinua el desig eròtic però se n'evita la referència explícita. L'escena de l'enamorament sempre presenta una rellevància especial dins la narració. Els enamoraments es produeixen en oca-

REVISTA VALENCIANA DE FILOLOGIA / I I (20I8) p. 85-IO8 SÒNIA GROS LLADÓS

Sobre la novel-la grega en Curial e Güelfa: la novella de Cimone / 96 
sions $\mathrm{i}$ indrets variats. Amb freqüència en una festa o celebració especial. Quéreas i Cal-lírroe en el decurs d'una festa, com Leucipe i Clitofont o Curial i Güelfa. Àntia i Habròcomes en una processó a la deessa Àrtemis, ${ }^{3}$ Teàgenes i Cariclea en una cerimònia religiosa a Delfos. Dafnis i Cloe, mentre el jove es banya a la gruta de les nimfes. En aquesta tradició l'escena de l'enamorament de Curial i Güelfa en la novel-la catalana ofereix una lectura coherent i esdevé l'inici de la seqüència habitual en aquest tipus de narracions: enamorament sobtat/separació i manteniment de la castedat dels enamorats/retrobament i matrimoni final (Gros 2014: 117).

8. L'amor és l'únic mòbil de l'enamorat i justifica els riscos i perills que assumeix. És alhora un element civilitzador i transformador de l'amant. Dona sentit a la seva existència i aconseguir la unió final dels enamorats esdevé l'objectiu exclusiu del relat, que constitueix un testimoni, com anunciava el narrador a l'inici de la història, del poder omnímode de l'amor: «ma quanto sian sante, quanto poderose e di quanto ben piene le forze d'Amore, le quali molti, senza saper che si dicano, dannano e vituperano a gran torto" (1991: 593). La metamorfosi de Cimone és radical i el noi es converteix en un breu lapse de temps en un jove gentil, amb maneres i gustos refinats en la indumentària, els costums, l'afició a les lletres i a la filosofia, i al que la novel·la catalana anomenarà «la disciplina militar». Es tracta, com ja ha estat observat (Gros 2015: 260-261), d'una transformació gairebé idèntica a la del jove Curial, que inclou com a element distintiu el domini del cant i la música d'un Cimone abans conegut per «la rozza voce e rustica» (1991: 594). Cimone, com Curial, esdevé d'aquesta manera, un jove extremadament distingit: «il più leggiadro e il meglio costumato e con più particulari virtù che altro giovane alcuno che nell'isola fosse di Cipri» (1991: 598).

Per a aquest efecte civilitzador de l'amor en el Cimone boccaccià suggeríem el model directe d'Habròcomes en les Efesíaques (Gros 2014: 121). Tanmateix, la novella de Boccaccio presenta una evident incongruència en el fet que

3 Precisament, com comentarem més endavant, l'humanista Poliziano inclou en Miscellaneorum centuria prima el passatge de la processó que se celebrava a Efes en honor d'Àrtemis, en la qual es produeix l'enamorament d'Àntia i Habròcomes (Misc. 51).

REVISTA VALENCIANA DE FILOLOGIA / I I (2OI8) p. 85-IO8

SÒNIA GROS LLADÓS

Sobre la novel-la grega en Curial e Güelfa: la novella de Cimone / 97 
Cimone (així com el secundari Lisimaco) mostra un comportament molt poc civilitzat amb Efigenia, ja que ambdós actuen com uns lladres, pirates i bandits, més que com els herois modèlics de la novel-la. Per bé que Cimone respecta la castedat de l'heroïna fins al matrimoni, li imposa en qualsevol cas els seus desitjos eròtics i la força a un matrimoni, sense que els lectors siguem partícips en cap cas dels sentiments d'Efigenia. No obstant això, si examinem la novella de Boccaccio en la tradició de la novel-la antiga, el rapte de Cimone evoca el que es narra al llibre IV de les Etiòpiques, quan Teàgenes, el protagonista, ajudat per uns companys, rapta Cariclea, que ha estat promesa en matrimoni a un altre pretendent, en la seva casa i fuig amb la jove en un vaixell fenici. Tot i la violència exercida sobre la noia, Teàgenes, model de fidelitat amorosa, respectarà la virginitat de Cariclea fins que es produeixi el matrimoni.

9. Malgrat la brevetat del relat, la trama principal es combina amb una trama amorosa secundària, la de Lisimaco i Cassandrea, paral-lela a la dels protagonistes, com és freqüent en les novel-les antigues. I precisament volem cridar l'atenció sobre alguns d'aquests relats breus intercalats en la narració principal. El primer és el de Cal-lígone i Cal-lístenes en Leucipe i Clitofont, suggerit per Gesner. Cal-lístenes, un jove ric, faldiller i malgastador, s'enamora de Cal-lígone per la fama de la seva bellesa. Enfurismat per la negativa del pare a concedir-li la noia com a esposa, determina raptar-la i consumar el seu desig per la força. Es produeix el rapte $\mathrm{i}$, apassionadament enamorat de la noia, Cal-lístenes sofreix una admirable transformació, esdevé un model de comportament exemplar i aconsegueix finalment que el pare accedeixi al matrimoni amb Cal-lígone. Apreciem el paral-lelisme de les dues històries i la mateixa argumentació com a justificació de la seva actuació violenta: «da voi come nemico e con l'armi m'ha costretto amore

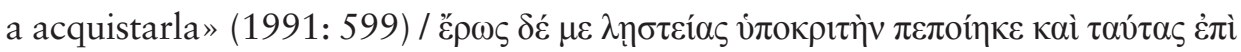

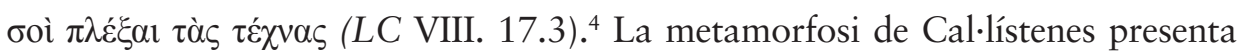
evidents elements en comú amb la de Cimone (i la de Curial): el jove es mostra prudent i magnànim, i sobretot sobresurt en l'entrenament militar i els exercicis

4 «Amor m'ha forçat a fer el paper de pirata i a tramar aquestes arts contra tu».

REVISTA VALENCIANA DE FILOLOGIA / I I (20I8) p. 85-IO8 SÒNIA GROS LLADÓS

Sobre la novel-la grega en Curial e Güelfa: la novella de Cimone / 98 


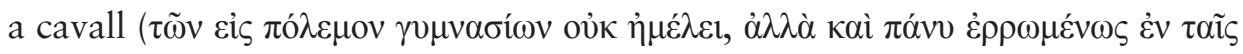

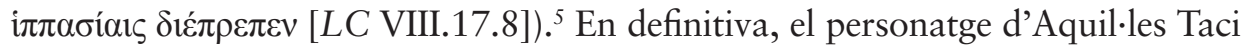

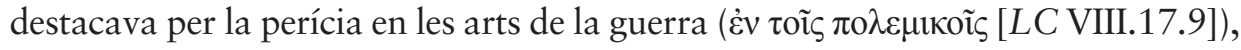
la «disciplina militar» del cavaller Curial, i el domini de les més variades tècniques en aquest àmbit. Tanmateix, l'antecedent més directe de Curial-Cimone l'hem d'identificar amb l'Habròcomes de les Efesíaques, que, a banda d'excel-lir en la disciplina militar i l'equitació, sobresurt per la bellesa extraordinària i les virtuts de l'anima, posseeix una educació acurada, domina les arts més diverses i desperta l'admiració dels seus conciutadans (Ef. I.1-2). ${ }^{6}$

Altrament, al llibre cinquè de les Efesíaques podem llegir la història de l'espartà Egialeu, el qual explica a Habròcomes, acabat d'arribar a Siracusa, com de jove es va veure forçat a raptar per la força la seva estimada i fugir amb ella davant l'oposició de les famílies d'ambdós a la unió. Egialeu, ara un vell pescador, havia format part d'una família noble i rica, però va haver d'escapar amb la noia, que havia estat promesa per la seva família a un altre home, amb la qual va poder viure feliç fins i tot després de la seva mort. Una altra trama argumental molt similar a la de la novella de Cimone.

10. La seqüència narrativa típica de les novel-les antigues correspon a un esquema força senzill i repetitiu, i es produeix la inevitable separació de la parella mitjançant un perillós viatge per mar, recurs emprat en totes les novel-les gregues que conservem excepte en la de Longus. Les aventures del relat boccaccià inclouen també els motius tòpics del gènere de la tempesta, l'assalt d'un vaixell, el rapte i la presó. Tots aquests motius els trobem presents també en el Curial, on el cavaller i el seu company Galceran pateixen una tempesta a les costes del nord d'Àfrica i el posterior assalt del vaixell, la captivitat i l'esclavitud durant un llarg període a l'alqueria del moro Fàraig. La seqüència narrativa

5 «No descurava la preparació per a la guerra i, ben al contrari, sobresortia molt especialment en els exercicis a cavall».

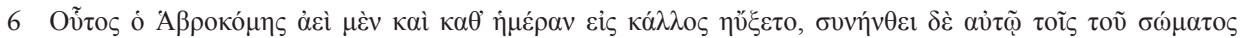

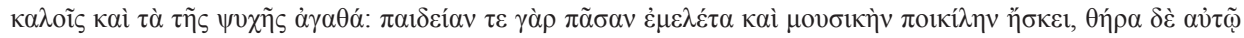

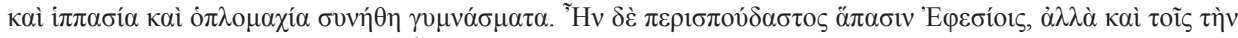

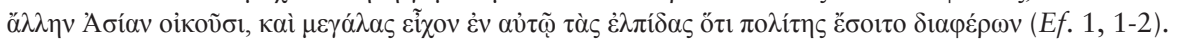

REVISTA VALENCIANA DE FILOLOGIA / I I (2OI8) p. 85-IO8

SÒNIA GROS LLADÓS

Sobre la novel-la grega en Curial e Güelfa: la novella de Cimone / 99 
finalitza amb l'habitual happy end del gènere: retrobament dels enamorats $\mathrm{i}$ matrimoni amb gran celebració. És un desenllaç joiós i inconcret que evoca el dels contes populars.

La composició de la narració és cuidada, amb una assolida alternança de morositat i precipitació en el relat, de perspectives dels personatges i un equilibri entre els passatges en estil directe i la narració del narrador omniscient, amb moments de dramatisme i espectacularitat. L'escena de l'assalt al vaixell en què Efigenia és transportada a Rodes, amb un Cimone abatent els enemics amb ferocitat, admet un clar paral-lelisme amb el Curial que assalta la galera d'Ambrosino de Spíndola.

A diferència del que succeïa en la novella II.7, no s'aprecia en aquesta narració cap element, com ara cap nota humorística, que permeti una interpretació còmica o fins i tot paròdica, com en el cas del conte d'Alatiel, de les convencions del gènere. Creiem, més aviat, que en aquesta novella Boccaccio utilitza els recursos narratius que li proporcionava la novel-la antiga d'amor i aventures per a la seva particular reescriptura d'una història que hem de situar inequívocament dins aquesta tradició. La seva extraordinària habilitat com a narrador dona un producte diferent però arrelat en la tradició antiga, de la qual utilitza els temes - amor i aventures-, nombrosos motius argumentals concrets, el perfil dels personatges, el marc espacial i l'ambientació hel-lenitzant, per plasmar en un format de novella o relat breu l'esquelet d'una veritable novel-la grega, amb tocs de dramatisme i espectacularitat. Una part considerable d'aquests trets característics del gènere antic arriben a la novel-la cavalleresca catalana, mitjançant la intermediació del certaldès, com atesten les intertextualitats documentades entre les dues obres. Comptat i debatut, contribueixen a la creació de l'atmosfera tan particular del Curial dins la tradició cavalleresca, amb la presència explícita del món grec, com ha estat posat en relleu per Júlia Butinyà en nombrosos treballs des de fa dècades, recollits molts d'ells en la seva monografia sobre la novel.la catalana (2001). Un aprofundiment en aquesta línia de recerca ens podria conduir a connexions amb textos sentimentals propers a la novel-la cavalleresca bizantina, on conflueix l'element sentimental de tradició grega amb el cavalleresc, com suggeria Redondo (2015: 405).

REVISTA VALENCIANA DE FILOLOGIA / I I (2OI8) p. 85-IO8 SÒNIA GROS LLADÓS

Sobre la novel-la grega en Curial e Güelfa: la novella de Cimone / Io० 
La novella de Cimone gaudí de l'estima de la posteritat. Fou traduïda al llatí per Filippo Beroaldo (Kristeller 1996: 361-2), juntament amb les novelle IV.1 i X.8 (1488-90), totes presents en la novel-la catalana. En la seva traducció l'humanista de Bolonya, pròxim a postulats neoplatònics, incideix particularment en els temes de la bellesa i l'amor (Viti 1975) i para especial esment en la imbricació dels models elegíacs llatins i el patró narratiu boccaccià. Així, per exemple, en la introducció al seu comentari a Properci, publicat el 1486, poc abans de la traducció de les novelle, Beroaldo realitza una lloança de l'amor: «Magnus deus est amor [...] qui mortalibus maximorum bonorum causa est, qui pacem largitur hominibus» (Viti 1975: 118), en què clarament evoca el propercià «Pacis Amor deus est, pacem ueneramur amantes» (III.5.1). Amb un clar ressò en la novel-la catalana: "Sabs bé que ma filla, Venus, és dea de concòrdia e de pau, e convida les gents a amar-se e voler-se bé...» (III. 299). ${ }^{7} \mathrm{Li}$ interessen figures femenines com Dido o Ariadna, i el món cultural i poètic dels clàssics llatins esdevé una referència contínua amb recreacions de motius, personatges i episodis producte de la seva freqüentació de la poesia llatina, en ocasions inexistents en l'original boccaccià (Viti 1975: 126-127). Una manipulació del material decameronià, en el cas de Beroaldo en format de traducció a la llengua llatina, que incorpora l'univers poètic dels autors clàssics, principalment els elegíacs, en una operació que, com ja ha estat observat (Gros 2015), vertebra el discurs sentimental del Curial. Beroaldo (1453-1505), insigne humanista de notòria formació classicista, va realitzar nombroses edicions i comentaris dels autors llatins, entre les quals les de Properci, Catul o Virgili. La coincidència dels materials poètics sobre els quals basteixen ambdós autors, Beroaldo i l'anònim del Curial, els seus treballs, el rerefons ideològic o els plantejaments estètics, contribueixen a situar-los en un ambient proper, malgrat la distància temporal de mig segle que els separa.

7 Soler (2018: II, 1177-1185) aprofundeix en les implicacions ideològiques d'aquesta visió de l'amor a partir del motiu de les dues Venus, i vincula l'anònim del Curial, Enyego d'Àvalos?, als cercles neoplatònics nord-italians. Sense entrar ara a discutir la qüestió de l'autoria, la nostra anàlisi corrobora els referents que proposa Soler.

REVISTA VALENCIANA DE FILOLOGIA / I I (20I8) p. 85-IO8

SÒNIA GROS LLADÓS

Sobre la novel-la grega en Curial e Güelfa: la novella de Cimone / IоI 


\section{El Laurentianus Conventi Soppressi 627 i Guarino de Verona}

El manuscrit Laurentianus Conventi Soppressi 627, única còpia que ens ha transmès la novel-la de Caritó completa i les Efesíaques, juntament amb les obres de Longus i Aquil-les Taci, és un manuscrit florentí del segle XIII (García Gual 1991: 192; Brioso 1997: 31). El còdex va romandre al monestir de La Badia, a Florència, d'on va passar a començament del segle XIX a la Biblioteca Medicea. Fou transcrit per Salvini el 1700, que en féu la primera versió a una llengua moderna, l'italià (1723), i a partir d'aquesta transcripció Antonio Cocchi realitzà l'editio princeps el 1726 a Londres (O'Sullivan 2014: 53). La recreació d'alguns episodis molt propers a les Efesíaques en la novel-la decameroniana d'Alatiel (II.7) planteja seriosos dubtes que qüestionen el desconeixement d'aquesta obra per part de Boccaccio (Deligiorgis 1967). De fet, sabem que el text de Xenofont era ben conegut durant el Renaixement, com prova que les Efesíaques, juntament amb Dafnis $i$ Cloe o l'obra d'Heliodor, foren citades per l'humanista i hel-lenista Poliziano, el 1489, en la seva Miscellaneorum centuria prima, obra reeditada diverses vegades entre 1496 i 1522, i posteriorment per H. Stephanus el 1561 (Perry 1967: 344-5; Gesner 1970: 152). ${ }^{8}$

Estudis com els de Blum (1951) o els més recents de Bianchi (2002, 2006) ens permeten actualment resseguir amb una certa seguretat la història d'aquest manuscrit, crucial per al coneixement de la difusió de les antigues novel-les gregues d'amor i aventures en el període anterior a les primeres edicions impreses. El manuscrit pertanyia a començament del segle xv a l'humanista florentí Antonio Corbinelli, el qual el llegà, juntament amb una magnífica col-lecció de dos-cents setanta-set manuscrits grecs i llatins, com a testament al monestir de La Badia de Florència el 1425. Corbinelli mantenia estretes relacions amb humanistes com Poggio Bracciolini, Niccolò Niccoli i, especialment, amb Guarino Veronese, al qual va hostatjar entre els anys 1410-1414, quan el famós pedagog es traslladà a Florència a impartir classes de grec. Guarino hauria emprat el

8 S'ha qüestionat que es tracti realment d'un codex unicus ja que Perry, seguint les recerques de Diller, indica l'existència d'altres testimonis, com ara una còpia del segle Xvi al Museu Britànic (1967: 344-5).

REVISTA VALENCIANA DE FILOLOGIA / I I (2OI8) p. 85-IO8 SÒNIA GROS LLADÓS

Sobre la novel-la grega en Curial e Güelfa: la novella de Cimone / IO2 
còdex i les novel-les, inclosa la de Xenofont, en les seves lliçons, segons afirmen Blum i Bianchi. Això explicaria, per exemple, la presència del pseudònim de l'estimada Anthia en l'Eroticon (1443), un recull d'elegies a imitació de Properci i Tibul, del poeta ferrarès Tito Vespasiano Strozzi, el qual havia après el grec a l'escola de Guarino. O la d'una Calliroe en la de Gaspare Tribraco de Tirimbocchi, poeta del mateix cercle humanístic de Ferrara i amic de Strozzi.

Soler relaciona directament Guarino Veronese (1374-1460) amb l'entorn de creació de la novel-la catalana (2018: I, 251-253). Guarino havia entrat al servei de Leonello d'Este, futur marquès de Ferrara, i, ateses les relacions familiars i polítiques dels Este amb el Magnànim, posteriorment entrà en contacte directe amb la cort napolitana, fins al punt d'enviar-hi el seu fill Girolamo al servei del rei d'Aragó. Soler no el connecta directament amb Enyego d'Àvalos, tot i que com a diplomàtic el camarlenc visitava la cort de Ferrara (1443-1447), però sí amb altres personatges de la cort del Magnànim com Joan Olzina, i amb molts dels humanistes italians del Quattrocento que vincula a la cort napolitana, com Bartolomeo Facio, Guiniforte Barzizza, Lorenzo Valla, Angelo Decembrio, Giovanni Aurispa o Flavio Biondo, els quals s'havien format en l'escola de Guarino a Ferrara. Soler recorda que en la dècada de 1440 Guarino havia dissenyat per als Este el projecte decoratiu de l'Studiolo di Belfiore, amb la representació d'Apol-lo i les nou Muses, i la presència de Venus Urània, protectora de l'amor honest i matrimonial (2018: II, 913-914). En l'exhaustiva recerca de Soler el nom de Guarino aflora contínuament darrere nombroses referències clàssiques, entre les quals autors grecs com sant Basili, Heròdot, Llucià, Estrabó o Teognis, i preocupacions de l'autor anònim. En particular, Soler relaciona Guarino amb els ideals educatius de la novel-la cavalleresca i el seu caràcter de speculum principis.

A més, Soler insisteix en la presència del context nord-italià i els corrents ideològics i estètics dominants en aquesta àrea, que detecta en la novel·la, postulant, d'acord amb Mesa (2012: 406), el perfil d'un autor que «compartia interessos, doncs, amb estudiosos de segona fila ben relacionats amb Poggio Bracciolini, Guarino Veronese i Francesco Filelfo» (2018: I, 780). Entre aquests interessos potser podríem situar-hi ara també el coneixement de les antigues

REVISTA VALENCIANA DE FILOLOGIA / I I (2OI8) p. 85-IO8

SÒNIA GROS LLADÓS

Sobre la novel-la grega en Curial e Güelfa: la novella de Cimone / IO3 
novel-les gregues ${ }^{9} \mathrm{i}$ aventurar la hipòtesi d'un contacte més pròxim amb aquests textos que el que s'havia defensat fins ara (Gros 2014: 137-138). És a dir, a la proposta de Boccaccio com a intermediari entre la novel-la antiga i Curial e Güelfa (Gros 2014), podríem afegir-hi en l'estat actual de la investigació el suggeriment d'altres lectures properes a l'autor (Enyego d'Àvalos?), procedents de l'entorn de l'humanisme florentí i ferrarès.

En aquesta mateixa línia, una anàlisi en profunditat de la connexió del Curial e Güelfa amb altres narracions de temàtica cavalleresca i amorosa vinculades a la tradició de la novel-la antiga d'amor i aventures com Impérios $i$ Margarona, Paris e Viana o Floire et Blancheflor, textos que compten a més amb traduccions tardomedievals al grec (Beaton 1996: 135 i seg.), podria resultar extremadament fructífera per a la contextualització genèrica de la novel·la catalana.

\begin{tabular}{|l|l|l|}
$\begin{array}{l}\text { Curial e Güelfa (ed. A. Ferran- } \\
\text { do [2007]) }\end{array}$ & $\begin{array}{l}\text { Decameron (ed. V. Branca } \\
[1991])\end{array}$ & Motius novel-lescos \\
\hline $\begin{array}{l}\text { Fonch ja ha lonch temps, segons } \\
\text { yo he legit, (en Cathalunya), un } \\
\text { gentil hom, ... apellat, lo qual... } \\
\text { (I. 43) }\end{array}$ & $\begin{array}{l}\text { Adunque (sì come noi nell'an- } \\
\text { tiche istorie de' cipriani abbiam } \\
\text { già letto) nell'isola di Cipri fu } \\
\text { un nobilissimo nomo il quale... } \\
\text { (V.1, 592) }\end{array}$ & $\begin{array}{l}\text { Recurs a una lectura del nar- } \\
\text { rador }\end{array}$ \\
\hline $\begin{array}{l}\text { la qual sens alguna comparació } \\
\text { traspassava en aquell temps la } \\
\text { bellesa de totes les donzelles de } \\
\text { Ytàlia (I. 45) }\end{array}$ & $\begin{array}{l}\text { "il quale di grandezza e di bel- } \\
\text { vani trapassava" (V.1, 594) }\end{array}$ & Bellesa extraordinària \\
\hline $\begin{array}{l}\text { tantost lo féu vestir e metre a } \\
\text { punt (I. 46) }\end{array}$ & $\begin{array}{l}\text { Egli primieramente richiese il } \\
\text { padre che il facesse andare di } \\
\text { vestimenti e d'ogni altra cosa } \\
\text { ornato come i fratelli di lui } \\
\text { andavano (V.1, 598) }\end{array}$ & Refinament de l'enamorat \\
\hline
\end{tabular}

9 Soler suggereix un possible contacte de l'autor del Curial amb Pausànias, a propòsit de l'associació Tura-Ventura i la figura de Tóxๆ (2018: III, 1012), mitjançant un manuscrit de Niccolò de Niccoli, traduït parcialment al llatí per Guarino. Ja s'havia remarcat anteriorment la possible presència de l'escriptor grec i la coincidència de l'aparició de Bacus en somnis a Èsquil recollida per Pausànias, amb la de Curial (Gros 2015: 163, n. 186).

REVISTA VALENCIANA DE FILOLOGIA / I I (20I8) p. 85-IO8

SÒNIA GROS LLADÓS

Sobre la novel-la grega en Curial e Güelfa: la novella de Cimone / Io4 


\begin{tabular}{|c|c|c|}
\hline $\begin{array}{l}\text { aprés gramàtica, lògica, rectòrica } \\
\text { e philosophia e fonch valent } \\
\text { home en aquestes sciències (I. } 46 \text { ) }\end{array}$ & $\begin{array}{l}\text { con grandissima ammirazione } \\
\text { d'ognuno, in assai brieve spazio } \\
\text { di tempo non solamente le prime } \\
\text { lettere apparò ma valorosissimo } \\
\text { tra' filosofanti divenne (V.1, } \\
\text { 598) }\end{array}$ & $\begin{array}{l}\text { Educació cultivada del prota- } \\
\text { gonista }\end{array}$ \\
\hline $\begin{array}{l}\text {...tantost fonch molt bell canta- } \\
\text { dor, e aprés sonar esturments- } \\
\text { de què devench molt famós-, } \\
\text { axí mateix cavalcar, trobar, } \\
\text { dançar, júnyer e totes altres ab- } \\
\text { teses que a noble jove e valerós } \\
\text { se pertanyian. (I. } 48 \text { ) }\end{array}$ & $\begin{array}{l}\text { non solamente la rozza voce e } \\
\text { rustica in convenevole e cittadi- } \\
\text { na ridusse, ma di canto divenne } \\
\text { maestro e di suono, e nel caval- } \\
\text { care e nelle cose belliche, così } \\
\text { marine come di terra, espertissi- } \\
\text { mo e feroce divenne. (V.1, 598) }\end{array}$ & Qualitats del protagonista \\
\hline $\begin{array}{l}\text { E sí pensà un jorn que sola } \\
\text { vergonya li tolia sos plaers, e } \\
\text { que, puys altre impediment no } \\
\text { y havia, ella la cuydava vençre e } \\
\text { venir a fi de son desig (I. } 49 \text { ). }\end{array}$ & $\begin{array}{l}\text {...volendo onesto fine porre al } \\
\text { suo disio, più volte fece tentare } \\
\text { Cipseo, padre d'Efigenia, che } \\
\text { lei per moglie gli dovesse dare } \\
(\text { V.1, 598) }\end{array}$ & Desig amorós \\
\hline $\begin{array}{l}\text { E en lo pits gentil, en lo qual al- } \\
\text { guna impressió de amorós plaer } \\
\text { encara no era entrat, súbitament } \\
\text { s'encés una flama foguejant, la } \\
\text { qual fins que mort lo ocupà no·s } \\
\text { pogué apagar. (I. } 50 \text { ) }\end{array}$ & $\begin{array}{l}\text { e nel rozzo petto, nel quale per } \\
\text { mille ammaestramenti non era } \\
\text { alcuna impressione di cittadine- } \\
\text { sco piacere potuta entrare, sentì } \\
\text { destarsi un pensiero il quale } \\
\text { nella materiale e grossa mente... } \\
\text { (V.1, 596) } \\
\text { Essendo adunque a Cimone nel } \\
\text { cuore, nel quale niuna dottrina } \\
\text { era potuta entrare, entrata la } \\
\text { saetta d'Amore per la bellezza } \\
\text { d'Efigenia... (V.1, 597) }\end{array}$ & Enamorament instantani \\
\hline $\begin{array}{l}\text {-e era la pus bella per fama } \\
\text { e per fet que en aquell temps } \\
\text { en l'imperi d'Alamanya se tro- } \\
\text { bàs-... (I. 73) }\end{array}$ & $\begin{array}{l}\text { gli ragionava costei essere la più } \\
\text { bella cosa che già mai per alcun } \\
\text { vivente veduta fosse (V.1, 596) }\end{array}$ & Bellesa extraordinària \\
\hline $\begin{array}{l}\text { membre-us de qui us ha fet } \\
\text { home, ço és, la Güelfa, a la qual } \\
\text { si a açò donats loch, convendrà } \\
\text { morir prestament, o haurà vida } \\
\text { dolorosa (I. } 78 \text { ) }\end{array}$ & $\begin{array}{l}\text { Ora è tempo di mostrare, o } \\
\text { Efigenia, quanto tu sii da me } \\
\text { amata. Io son per te divenuto } \\
\text { uomo: e se io ti posso avere, io } \\
\text { non dubito di non divenire più } \\
\text { glorioso che alcuno idio: } \\
\text { e per certo io t'avrò o io morrò. } \\
\text { (V.1, 599) }\end{array}$ & $\begin{array}{l}\text { Efecte transformador de l'amor } \\
\text { Patiment d'amor }\end{array}$ \\
\hline
\end{tabular}

REVISTA VALENCIANA DE FILOLOGIA / I I (2OI8) p. 85-IO8

SÒNIA GROS LLADÓs

Sobre la novel-la grega en Curial e Güelfa: la novella de Cimone / Io5 
E, jatsia a mi ésser molt dura cosa voler-me treballar en escalfar sanch ja freda e gelada, $e$ cor en lo qual alguna impressió de natural calor no viu ne regna (II. 223)

Curial, saltant de la popa ab los seus, alguns ab hatxes, emperò los demés ab les spases en les mans, fan-se avant, e quisque fonch aconseguit, mort o nafrat cahia o tornava atràs...

(III. 279)

Molts foren los convits, grans foren les festes que per aquest matrimoni se feren e.s celebraren en París. (III. 388)

[lo príncep e la princesa] benaventuradament en les sues terres ab molta alegria tornaren (III. 389) e nel rozzo petto, nel quale per mille ammaestramenti non era alcuna impressione di cittadinesco piacere potuta entrare (V.1, 596)

...sopra la nave de' rodiani saltò, Peripècies marines

quasi tutti per niente gli avesse;

e spronandolo amore, con ma-

ravigliosa forza fra' nemici con un coltello in man si mise e or questo e or quello ferendo quasi pecore gli abbattea. (V.1, 600)

Venuto il giorno delle nozze, la Matrimoni final dels enamorats pompa fu grande e magnifica, e ogni parte della casa de' due fratelli fu di lieta festa ripiena (V.1, 607

dopo alcuno essilio Cimone con Efigenia lieto si tornò in Cipri e Lisimaco similmente con Cassandrea ritornò in Rodi; e ciascun lietamente con la sua visse lungamente contento nella sua terra (V.1, 608)

\section{Bibliografia}

Achilles Tatius (1858) Erotici Scriptores Graeci, 1, R. Hercher (ed.), Leipzig, Teubner. Balcells, J. (ed.) (2012 [1946]) Properci, Elegies, Barcelona, Fundació Bernat Metge. Beaton, R. (1996 [1989]) The Medieval Greek Romance, Londres/Nova York, Routledge. Berenguer, J. (trad.) (1963) Longus. Dafnis i Cloe, Barcelona, Vergara.

Bianchi, N. (2002) «Poliziano, Senofonte Efesio e il codice Laur. Conv. Soppr. 627», Quaderni di Storia, 55, p. 183-214.

- (2006) Il codice del romanzo. Tradizione manoscritta e ricezione dei romanzi greci, Bari, Edizioni Dedalo.

Blum, R. (1951) La biblioteca della Badia Fiorentina e i codici di Antonio Corbinelli, Città del Vaticano, Biblioteca Apostolica.

Boccaccio, G. (1991) Decameron, Vittore Branca (ed.), Torí, Einaudi.

Brioso, M. (trad.) (1997) Longus, Dafnis y Cloe; Aquil.les Taci. Leucipe y Clitofonte, Madrid, Gredos.

REVISTA VALENCIANA DE FILOLOGIA / I I (2OI8) p. 85-IO8

SÒNIA GROS LLADÓS

Sobre la novel-la grega en Curial e Güelfa: la novella de Cimone / Io6 
Butinyà, J. (2001 [1999]) Tras los orígenes del humanismo: el «Curial e Güelfa», Madrid, UNED. Carilla, E. (1966) «La novela bizantina en España», Revista de Filología Española, 49, Iss. 1, p. $275-287$.

- (1968) «Cervantes y la novela bizantina (Cervantes y Lope de Vega)», Revista de Filología Española, 51, Iss. 1, p. 155-167.

Crespo, E. (trad.) (1979) Heliodor, Las Etiópicas o Teágenes y Cariclea, Madrid, Gredos.

Deligiorgis, S. (1967) «Boccaccio and the Greek romances», Comparative Literature, 19/2, p. $97-113$.

Ferrando, A. (ed.) (2007) Curial e Güelfa, Tolosa de Llenguadoc, Anacharsis Éditions.

García Gual, C. (1991) Los orígenes de la novel-la, Madrid, Istmo.

- (2007) «Menéndez Pelayo y sus estudios sobre las novelas griegas y latinas, antes y en sus Orígenes de la novela», dins Orígenes de la novela: estudios: ponencias presentadas al congreso I Encuentro Nacional Centenario de Marcelino Menéndez Pelayo celebrado en Santander los días 11 y 12 de diciembre de 2006, R. Gutiérrez Sebastián (ed. lit.), B. Rodríguez Gutiérrez (ed. lit.), Santander, Servicio de Publicaciones de la Universidad de Cantabria - Sociedad Menéndez Pelayo, p. 71-107.

Gesner, C. (1970) Shakespeare \& the Greek Romances. A study of origins, Lexington, The University Press of Kentucky.

Gros, S. (2011) La temática amorosa en «Curial e Güelfa». Una aproximación desde la tradición clásica, Madrid, UNED [tesi doctoral. Recurs electrònic].

- (2014) «Boccaccio i la novel·la grega en el Curial e Güelfa», Studia Iberica et Americana, 1, p. 94-126. <http://www.researchgate.net/publication/271326665_Boccaccio_i_la_novella_grega_en_el_Curial_e_Guelfa>

— (2015) «Aquella dolçor amarga». La tradició amatòria clàssica en el «Curial e Güelfa», València, PUV.

— (2016) «Sobre la recepció dels clàssics grecollatins en el Curial e Güelfa: el tòpic de l'aegritudo amoris», dins La traducció (in) directa dels clàssics a les literatures hispàniques, entre més, J. J. Pomer Monferrer i J. Redondo Sánchez (ed.), Amsterdam, Adolf M. Hakkert Publisher, p. 61-88.

- (2018) «Horace in Curial e Güelfa?, dins New approaches in the Research on the Crown of Aragon, A. Cortijo \& V. Martines (ed.), Mirabilia/MedTrans 07, 2018/1, p. 53-75.

HäGG, T. (1983) The Novel in Antiquity, Oxford, Blackwell.

Hernández, M. (1997) «Boccaccio y el mundo clásico», Analecta Malacitana, 20, 1, p. 73-94. Imprès.

— (ed. i trad.) (2005) Boccaccio, G. Decameron, Madrid, Cátedra.

Hualde, P. (2015) «Nuevos datos sobre traducciones de novela griega en España durante el siglo XIX», Myrtia, 30, p. 255-268.

Kristeller, P. O. (1996) Studies in Renaissance Thought and Letters IV, Roma, Edizioni di Storia e Letteratura.

REVISTA VALENCIANA DE FILOLOGIA / I I (2OI8) p. 85-IO8

SÒNIA GROS LLADÓs

Sobre la novel.la grega en Curial e Güelfa: la novella de Cimone / Io7 
Mendoza, J. (trad.) (1979) Caritó d'Afrodísia. Quéreas y Calírroe. Xenofont d'Efes, Efesíacas. Fragmentos novel-lescos, Madrid, Gredos.

Mesa, J. F. (2012) «Las fuentes del latín del Curial e Güelfa», dins Linguistic and Cultural Studies on Curial e Güelfa, a Xvth century anonymous chivalric romance in Catalan language, A. Ferrando (ed.), Amsterdam, John Benjamins/IVITRA, p. 387-428.

Miralles, C. (ed. i trad.) (1967) Xenofont d'Efes, Efesíaques, Barcelona, Fundació Bernat Metge.

- (1968) La novela en la antigüedad clàssica, Barcelona, Labor.

O'Sullivan, J. M. (2014) «Xenophon. The Ephesian Tales», dins A Companion to the Ancient Novel, E. P. Cuevas \& S. N. Byrne (ed.), Oxford, Wiley-Blackwell, p. 43-60.

Perry, B. E. (1967) The Ancient Romances. A Literary-Historical Account of their origins, Berkeley/Los Angeles, University of California Press.

Poliziano, A. (1489) Miscellaneorum centuria prima, Florència, Biblioteca Nazionale Centrale de Firenze. <https://archive.org/details/ita-bnc-in1-00000651-001>

Pomer, J. J. (2014) «Les cartes d'amor a la novel-la grega antiga i al Curial e Güelfa», Scripta Revista Internacional de Literatura i Cultura Medieval i Moderna, 4, p. 1-10.

Rattenbury, R. M. (ed.) (1960) Heliodor, Les Éthiopiques: Théagène et Chariclée, París, Les Belles Lettres.

Redondo, J. (2015) «Ressenya a Sònia Gros Lladós, “Aquella dolçor amarga”. La tradició amatòria clàssica en el "Curial e Güelfa", València, Publicacions de la Universitat de València, 2015», Tirant, 18, p. 403-406.

- (2018) «Èsquil al Curial e Güelfa», Scripta. Revista Internacional de Literatura i Cultura Medieval i Moderna, 11, p. 22-34.

Rojas, L. (2012) «Ecos de la novela griega en el Renacimiento», Synthesis, 19, p. 15-27.

Ruiz, C. (2006) La novela griega, Madrid, Síntesis.

Soler, A. (2018) La cort napolitana d'Alfons el Magnànim: el context de Curial e Güelfa, València, Publicacions de la Universitat de València, 3 vol.

Torres, J. B. (2009) « ¿Novela bizantina o novela helenizante? A propósito de un término consagrado", dins Ars bene docendi. Homenaje al Profesor Kurt Spang, I. Arellano, V. García i C. Saralegui (ed.), Pamplona, Eunsa, p. 567-74.

Viti, P. (1975) «Filippo Beroaldo traduttore del Boccaccio», Rinascimento, 15, p. 111-140. Whitmarsh, T. (ed.) (2008) The Cambridge Companion to the Greek and Roman novel, Cambridge, Cambridge University Press.

REVISTA VALENCIANA DE FILOLOGIA / I I (20I8) p. 85-IO8

SÒNIA GROS LLADÓS

Sobre la novel-la grega en Curial e Güelfa: la novella de Cimone / Io8 